\title{
Dialogical positions in a Whatsapp group regarding the use of chloroquine and
}

\section{hydroxychloroquine in the treatment of Covid-19}

\author{
Posições dialógicas em um grupo do Whatsapp em relação ao uso de cloroquina e \\ hidroxicloroquina no tratamento de Covid-19 \\ Posiciones dialógicas en un grupo de Whatsapp sobre el uso de cloroquina e hidroxicloroquina en el
} tratamiento del Covid-19

Received: 08/19/2021 | Reviewed: 08/25/2021 | Accept: 08/28/2021 | Published: 08/31/2021

\author{
José Anchieta de Oliveira Bentes \\ ORCID: https://orcid.org/0000-0003-1134-3677 \\ State University of Pará, Brazil \\ E-mail: anchieta2005@yahoo.com.br \\ Rita de Nazareth Souza Bentes \\ ORCID: https://orcid.org/0000-0001-7565-7224 \\ State University of Pará, Brazil \\ ORCID: ritabentes28@gmail.com \\ Helen do Socorro Rodrigues Dias \\ ORCID: https://orcid.org/0000-0002-2203-6421 \\ State University of Pará, Brazil \\ ORCID: helensrdias@yahoo.com.br \\ Josane Daniela Freitas Pinto \\ ORCID: https://orcid.org/0000-0003-0644-3219 \\ State University of Pará, Brazil \\ ORCID: josane.daniela@uepa.br
}

\begin{abstract}
The objective of this article is to analyze the established discourses in conversations among members of WhatsApp group "Academia Saudável” (Healthy Academy), having as central issue the controversy of the use of chloroquine and hydroxychloroquine medicines in the treatment of Covid-19. For the analysis, the concepts of concrete utterance, responsible act, alien and authorial discourse, field of communication and discourse genres of Bakhtin's Dialogical Theory of Language and the Circle were summoned. The results demonstrate that each individual of the group has a prominent role in guaranteeing the conversation theme through his/her discursive positionings favorable or not to the use of these drugs in the fight against the new coronavirus.
\end{abstract}

Keywords: WhatsApp conversations; Discursive positions; Dialogic analysis.

\section{Resumo}

O objetivo deste artigo é analisar os discursos estabelecidos nas conversas entre membros do grupo WhatsApp “Academia Saudável”, tendo como questão central a polêmica do uso dos medicamentos cloroquina e hidroxicloroquina no tratamento da Covid-19. Para a análise, foram convocados os conceitos de enunciado concreto, ato responsável, discurso alheio e autoral, campo da comunicação e gêneros discursivos da Teoria Dialógica da Linguagem de Bakhtin e do Círculo. Os resultados demonstram que cada indivíduo do grupo tem papel de destaque em garantir o tema da conversa por meio de seus posicionamentos discursivos favoráveis ou não ao uso dessas drogas no combate ao novo coronavírus.

Palavras-chave: Conversas de WhatsApp; Posições discursivas; Análise dialógica.

\section{Resumen}

El objetivo de este artículo es analizar los discursos establecidos en las conversaciones entre miembros del grupo de WhatsApp "Academia Saludable", teniendo como tema central la controversia sobre el uso de cloroquina e hidroxicloroquina en el tratamiento del Covid-19. Para el análisis se convocaron los conceptos de enunciado concreto, acto responsable, discurso ajeno y autoral, campo de la comunicación y géneros discursivos de la Teoría Dialógica del Lenguaje de Bakhtin y el Círculo. Los resultados demuestran que cada individuo del grupo tiene un papel destacado en asegurar el tema de conversación a través de sus posiciones discursivas favorables o no al uso de estos fármacos en el combate al nuevo coronavirus.

Palabras clave: Conversaciones de WhatsApp; Posiciones discursivas; Análisis dialógico. 


\section{Introduction}

"It is impossible to determine its [each utterance's] position without correlating it with other positions" (Bakhtin, 1986).

Subjects that use social networks have the purpose of interacting with the other, to position themselves on any topic, giving their opinion for or against it, or aiming not to know about a given theme, such as the coronavirus pandemic. This article aims to analyze the discursive positions established in conversations on the WhatsApp application regarding the use of chloroquine and hydroxychloroquine drugs to combat Covid-19.

Social networks are one of the fields of human communication. In this field, WhatsApp conversations are engendered by discursive positionings as several ideological propositions which are established in the interaction between subjects.

These positionings are constructed within the relationship of alien discourses in several other fields: in politics, in science and in the media. These latter influence, above all, the position of each subject open to dialogue, in company groups, family groups, sports groups, among others.

In the political field, we highlight the Bolsonarist ${ }^{1}$ Discourse. It brings an institutional ideological positioning, maintaining as its primacy to print an authoritarian position; in the scientific field, researchers study and disseminate their research, proving their truths through concrete information; and, in the Mediatic field, facts and research results are disseminated, some achieving better audience and repercussion. The truth in each of these fields can be used to maintain or combat dominant relations of power and oppression.

The vast majority of discourses in social networks that discuss about coronavirus are vectors for the spread of ideologies that defend discourses of absolute truth in the Brazilian context, without accepting conter-arguments or listening to other opinions, especially in public policies to combat the pandemic.

Thus, following the discursive flow, we bring the following question: how are discursive positionings constituted in the tension of WhatsApp conversations about the use of chloroquine and hydroxychloroquine drugs in the treatment of Covid$19 ?$

\section{Methodology}

This research is a dialogic discourse analysis based on the theoretical and methodological conceptions of Bakhtin and the Circle. The choice of this reference serves us for an analysis beyond the linguistic aspects towards a metalinguistic look, a study of the concrete discourse that emerges from the interaction about the controversies present in the Whatsapp group regarding the discursive positioning about the use of chloroquine and hydroxychloroquine drugs in the treatment of Covid-19.

[...] Metalinguistic researches, of course, cannot ignore their results. Linguistics and metalinguistics study the same concrete, very complex and multifaceted phenomenon - discourse, but they study it from different aspects and different angles of view. They should contemplate each other and not merge. (Bakhtin, 2010, p. 207)

In this dialogic perspective about the positionings for and against, a living reality of the individuals of language is established involved in this research of qualitative nature, according to the understanding of Ludk and Andre (1986) a qualitative research is constituted by a researcher involved with the concrete object, considering the totality of research procedure, based on the locus, individuals and events, valuing more the process than the product.

\footnotetext{
${ }^{1}$ The term Bolsonarist is used to refer to people who support Brazilian President (2019 -) Jair Bolsonaro.
} 
For an analysis of qualitative nature in the Human Sciences, in which we identify ourselves, we consider the following parameters:

1) The psychophysiological perception of the physical sign (word, color, shape, spacial). 2) Its interaction (with what is known or unknown). The comprehension of its reproducible meaning (generates) in language. 3) The understanding of its meaning in a given context (nearer or farther). 4) The active-dialogical understanding (discussion-agreement). (Bakhtin, 2017, p.63)

Among these parameters presented by the author, we will use only the fourth, the active-dialogical understanding, which is presented in the alternation of the discourses that occurred during the polemic concerning the treatment of Covid-19.

We will base our analysis on the theoretical and methodological concepts of Bakhtin and the Circle: "responsive act", "concrete enunciation", "authorial and alien discourse", besides the concepts of "discourse genre" and "field of human communication", complementing the meaning of the concept of enunciation in the discussion.

The Bakhtinian concepts govern two other key concepts, such as: "word and counter-word of propagating the treatment" and "word and counter-word of denying reality", constituting two controvertial discourses as a category of analysis: the absolute discourse - which does not enable dialogue by denying other voices - and the relational discourse, which recognizes the multiple voices, through the listening to voices outside the established dialogic relations.

Thus, the corpus of this research is constituted by students and teachers of the WhatsApp group "Academia Saudável” (AS group) (Healthy Academy), from Belém-PA, which due to the pandemic had its activities suspended. Twenty-eight subjects participated in the discussion, which took place on May 17, 2020, from 2:24am to 11:02am, around the theme of pandemic. This conversation is constituted of 30 insertions, which will be analyzed in the light of the dialogic theory of discourse.

\section{A Brief Retrospective of Events: a Necessary Review}

In the end of 2019, the SARS-CoV-2 virus changed the world, as an ecological-health crisis without the prospect of an immediate cure, forcing much of the population into quarantine. The contamination in humans began in Wuhan City, Hubei Province, China, in the months of October and November 2019.

It is a virus that is still little known by science ${ }^{2}$ and extremely contagious. It manifests itself through human secretions when sneezing, speaking, breathing, or touching any contaminated object, according to the concept adopted by the Getúlio Vargas Foundation ${ }^{3}$ :

Coronaviruses are a large family of viruses that cause disease in humans and animals. In humans, several coronaviruses are known to cause respiratory infections, which can range from a common cold to a more serious illness, such as SARS and MERS. The new coronavirus causes the disease called Covid-19 (FGV, 2020, p. 3).

As we said, all research regarding the new coronavirus is very recent. However, this crisis has affected people's everyday lives, becoming the central theme of daily conversations between people in all fields of communication, especially in world politics.

\footnotetext{
${ }^{2}$ We note that new studies indicate discussion that "Covid-19, the disease caused by the new coronavirus (Sars-CoV-2), is a systemic disease and it is already relatively well-established among professionals. That is, its damage and symptoms are not limited to the airways and lungs much of the body can be affected" (Pinheiro, 2020, p. 1).

${ }^{3}$ Getúlio Vargas Foundation (FGV) adopts the World Health Organization's speech: "Coronaviruses are a large family of viruses found both in animals and humans. Some infect humans and are known to cause a variety of conditions, from the common cold to more serious illnesses, such as Middle-East respiratory syndrome (MERS) and severe acute respiratory syndrome (SARS)" (OMS, 2020, p. 1).
} 
For this study, we selected the main political, scientific, and mediatic events, which occurred between March 16 and June 4, 2020, in order to recover the memory of the research object in blogs and online text newspapers from May 2020. We used the descriptors "chloroquine" and "hydroxychloroquine", which allowed us data that evidence all the controversy about the use of "chloroquine" and "hydroxychloroquine". From this choice, we elected the significant speeches of representatives involved with the theme about the use of these medications, keeping the object open to the understanding by the researchers that "The complex dialectic of inside and outside. The individual has not only means and environment, but also his own horizon. The interaction [...] of the horizon of the cognoscent subject with the horizon of the knowable object" (Bakhtin, 2017, 58). The subjects in the research need to interact with materiality in favor of a response to society, with the interacting consciousnesses of the self and the other, as we note in the course of events below:

Event 01: The first applications of "chloroquine" and "hydroxychloroquine", drugs originally used to treat malaria, which started to be used experimentally as anti-inflammatory and antiviral drugs in China. The French doctor of infectious diseases Didier Raoult applied these drugs to his patients in the city of Marseille and published, on March 16, 2020, together with other researchers, a small clinical trial: "Hydroxychloroquine and azithromycin as a treatment of Covid-19: results of an open-label non-randomized clinical trial, International Journal of Antimicrobial Agents (2020)". (Hime; Costa, 2020, p. 1).

Event 02: President Donald Trump takes notice of this clinical trial and disseminates hydroxychloroquine as a solution to the coronavirus pandemic on March 19, 2020. Trump is the first world leader to advertise a treatment, asking the Food and Drug Administration (FDA) to rush the permission for the use of hydroxychloroquine to fight the new coronavirus, getting its approval on March 30 (Rowland, 2020).

Event 03: President Jair Bolsonaro aligns with the president of the United States and determines the large-scale production of hydroxychloroquine by the Brazilian Army's Chemical and Pharmaceutical Laboratory, on March 21, 2020. And the National Sanitary Vigilance Agency (ANVISA) approves of the distribution of the base drug of chloroquine and hydroxychloroquine "without the need for a two-way Special Control Prescription" (Reis, 2020, p. 1).

Event 04: President Jair Bolsonaro, in a nationally broadcast radio and TV address, speech on March 24, 2020, radicalizes with a position of denial regarding the consequences of coronavirus, claiming to have "a history of being an athlete", stating that if he were contaminated by the coronavirus, he would feel almost nothing, because "it would be just a 'little flu' or a 'little cold'". Moreover, he declares he is against the mass confinement decreed by governors and mayors (BBC News, 2020, p. 1).

Event 05: the Ministry of Health establishes, on March 25, 2020, a protocol for distribution to all states of the nation of 3.4 million of chloroquine and hydroxychloroquine to be used in patients in serious conditions, admitted to hospitals, to be applied under medical supervision (Cancian; Saldaña, 2020).

Event 06: President Jair Bolsonaro, in a new address to the nation on March 31, 2020, announces the production of one million chloroquine tablets: "The virus is a reality. There is still no vaccine against it or medicine with scientifically proven efficiency, although hydroxychloroquine seems quite effective. The coronavirus came and one day it will go away. Unfortunately we will have losses on this path" (Brasil247, 2020, p. 1). The statements made by the president gave reason to the title of the page of Brasil247, "Bolsonaro says there are no proven studies on chloroquine, but ordered to produce more".

Event 07: on April 05, 2020, the Metrópole journal states that hydroxychloroquine, which is the basis of the drug Reuquinol, "is produced by a pharmaceutical company [Apsen] which is owned by a great enthusiast of Bolsonarism [Renato Spallicci]" (Veleda \& Waltenberg, 2020, p. 1).

Event 08: according to The New York Times, in the April 06, 2020, President Donald Trump makes an energetic defense of hydroxychloroquine: "Trump's Aggressive Advocacy of Malaria Drug for Treating Coronavirus Divides Medical Community" (Baker; Rogers; Enrich; Haberman, 2020, p. 1). The newspaper states that President Trump owns stocks of 
Sanofi, a French pharmaceutical industry, which manufactures chloroquine for sale under the names Plaquenil and Plaquinol. The newspaper points out that the president does not consider the decisions of the medical community, since the drug has not been tested yet and its efficiency has not been proven yet.

Event 09: a consortium of researchers consisting of the Tropical Medicine Foundation of the Capital of Amazonas in Manaus, the Oswaldo Cruz Foundation (Fiocruz) of the University of São Paulo and the Amazonas State University (UEA) began to suffer death threats in social networks by Bolsonarist "militants", when it was released on April 06, 2020 a clinical research with 81 patients hospitalized by the new coronavirus, with the result that "they benefited discreetly from chloroquine and that the results encouraged continuity, but that in higher doses, the drug can indeed cause severe arrhythmias and lead to death" (Maisonnave, 2020, p. 1).

Event 10: The governors of several states purchase chloroquine and hydroxychloroquine-based medications and start creating protocols for their use by patients with the first symptoms and for patients who already have lung infections. Among these, the governor of Piauí, from the Workers' Party (PT), stands out: "Our doctors are drawing up this protocol that provides safety for both the doctor and the patient. They are dialoguing with professionals from Ceará and Pará, and this document should be ready by Wednesday (April 08, 2020)" (cidadeverde.com, 2020, p. 1).

Event 11: former Minister of Health, Luiz Henrique Mandetta is fired on April 16, 2020, after making a statement on Rede Globo's Fantástico TV program, that the country "does not know whether to listen to the minister or to the president" (LEÃO, 04/16/2020, p. 1). He defended public measures of social distancing and was against the use of hydroxychloroquine, according to the headline of DCM: "Mandetta humiliates Bolsonaro, says he will keep isolation and that chloroquine only if it goes through science" (Cassio, 2020, p. 1).

Event 12: President Jair Bolsonaro signs Provisional Measure 966/2020, on May 14, 2020. This legal act "exempts public agents from responsibility for action and omission in actions related to the pandemic of the new coronavirus" (Verdélio, 2020 , p. 1), to avoid problems with spending public money on the production of an ineffective medication during the pandemic.

Event 13: the following Minister of health, Nelson Teich, resigns on May 15, 2020, for not agreeing with the strategy of broad use of hydroxychloroquine. The minister's statement is that "he could not change the protocol without scientific proof" (Cancian; Fernandes; Chaib; Coletta, 2020, p. 1). President Jair Bolsonaro wanted to extend this protocol to mild cases of Covid-19.

Event 14: The Soterro Therapeutics Company, on May 15, 2020, from the State of California, announces the discovery of an antibody that blocks the development of coronavirus. A report published by UOL says the company "does not explain how the experiment was done nor does it says what kind of cells were used in the laboratory [...] it says that the antibody called STI-1499 would have the ability to block the mechanism that the parasite uses to invade human cells and cause infection" (Batista, 05/15/2020, p. 1).

Event 15: on May 20, 2020, the Ministry of Health approves a new extension protocol of hydroxychloroquine for mild cases of coronavirus, through an unsigned document. He explained that "it is a publication with guidelines from several areas of the Ministry of Health and that, as well as other documents, there is no need for a signature" (G1, 2020, p. 1). Referring to the release of the much desired protocol, the President ironically declared: "What is democracy? You don't want it? You don't do it. You are not forced to take chloroquine," he said. " Those who are on the right take chloroquine. Those on the left take Tubaína [a type of soft drink]" (Sputniknews Brazil, 2020, p. 1).

Event 16: The Lancet magazine publishes an extensive research with 100,000 patients on May 23, 2020, showing that the drug is not effective in fighting the new coronavirus, and causes the risk of death to patients (RFI, 2020). However, the authors in this same journal published a retraction note on April 06, 2020 with the following argument: "The scientists said 
they could no longer vouch for the veracity of the primary data sources used to support the research, which had found risk in the use of substances against the new coronavirus (G1, 2020, p. 1).

As we have seen, the polemics of the use of chloroquine and hydroxychloroquine began with the release of a small clinical trial by the doctor Didier Raoult, in Italy, which was taken up by U.S. President Donald Trump as a discourse of absolute truth for the cure of Covid-19. Soon, Brazilian president Jair Bolsonaro assumes the same ideological position, without scientific proof, as the main symbol of his government in the face of the global ecological-sanitary crisis. And he immediately authorizes the ample production of the medication in the country by the Brazilian Army.

In order to avoid any fiscal responsibility lawsuits, in May, the government edits the Provisional Measure 966/2020, to prevent the punishment of mistakes made by public agents during the fight against the new coronavirus. Thus, due to the government's insistence on the indiscriminate use of these medications, two Ministers of Health, who were physicians themselves, resigned between April and May in 2020.

In parallel, since the beginning of the dissemination of chloroquine and hydroxychloroquine in the treatment of Covid-19 there was a wide circulation of news through social networks in the country, trying to annul all research that questioned the use of these drugs, threatening researchers, reinforcing the denialist position as occurred in Amazonas State in April, 2020. Moreover, the Ministry of Health has been omitting the real data on the number of infected people and deaths, hindering scientific research in comparative terms of the progress of the disease.

Another form of denying the facts occurs on the part of the Bolsonarists. Bolsonarism is an ideological discourse of the political field that has its icon in the President Jair Bolsonaro and is disseminated by his supporters. These discourses aim, in their logic and architecture, to maintain a loyal group of voters, to persuade, to create a way of seeing reality, to attack an "ideological" enemy with the purpose of printing an authoritarian and always aggressive position.

The ideological discourse of Bolsonarism is based, by principle, on the triangulation god-nation-family, and presents the following characteristics: a) the defense of a divine choice: the president is God's choice to defend the homeland and the family; b) criticism towards the communist enemy: all who contradict him or oppose his principles are labeled as communists; c) the defense of the innocence of children: criticizing their early eroticization and labeling as pedophiles all those who oppose that position; d) the defense of an imaginary "good citizen", as they call the defenders of those proposals; e) the criticism toward the press for not publicizing that point of view, with the accusation of always distorting Bolsonaro's words; e) the defense of the free market, understood here as neoliberalism; f) the defense of freedom of consumption and circulation, not admitting the social isolation of people due to the pandemic of the coronavirus; g) the objection to any scientific explanation that comes from the university and the great scientific circles.

\section{Theoretical Dialogues: From Concepts to Concrete Discussions}

Tracking our research object was essential to understand how the discourses present in the memory reflect and refract the statements in favor or against the use of hydroxychloroquine and chloroquine to combat Covid-19. We summoned theoretical concepts from Bakhtin and the Circle for the analysis of the discourses that are constructed in WhatsApp group conversations: the "concrete utterance" and the "responsible act" by Bakhtin (1993;1986), the "alien and authorial discourse" by Volochinov (2017). The concepts of communication field and discourse genre are called upon for the understanding of WhatsApp conversations.

In this sense, concrete utterance is considered as the most different forms of communication that are uttered by subjects within a dialogue, in terms that "Any utterance is a link in the chain of speech communion. It is the active position of the speaker in one referentially semantic sphere or another" (Bakhtin, 1986, p. 84). 
The conversations that take place in the WhatsApp ${ }^{4}$ application are therefore a speech genre engendered by concrete utterances from the lives of those involved and expressing ideologies, beliefs or valuations in a particular field, since "each separate utterance is individual, of course, but each sphere in which language is used develops its own relatively stable types of these utterances. These we may call speech genres" (Bakhtin, 1986, p. 60), which permeate the social life of all subjects with numerous possibilities of forms.

We also emphasize that "every utterance is full of varied responsive attitudes to other utterances in a given field of discursive communication" (Bakhtin, 2016, p. 57). The subjects must be at the center of the discussion with their unique singularities, valuations, and responsibilities, whatever discursive genre it is and in whatever field it is determined. An "obligatory singularity" of "my non-alibi in Being" (Bakhtin, 1993, p. 19). And in WhatsApp conversations, according to the topics under discussion, the members position themselves assuming the dialogic character with the other, either accepting the reality of the pandemic of the new coronavirus or denying this reality.

The movement of the exist-event constitutes the meaning of a WhatsApp conversation from "the basic concrete moments of its construction and their mutual disposition. These basic moments are I-for-myself, the other-for-me, and I-forthe-other" (Bakhtin, 1993, p. 54).

In this sense, the WhatsApp group conversations are taken as a language space that allows us to actively dialogue as a responsible and responsive subject based on the different controversial discussions. Responsiveness is the existence of the subject in its responsible act, understanding, in this way, the responsible act as a unique moment, unrepeatable from the consciousness of the subjects constituted in their architectures of life and culture.

Such responsibility is materialized in the tensions between subjects based on their dialogical relations, in which they simultaneously alter themselves, that is, they appropriate other people's words to meet their own. We understand alien discourse as "speech within speech, utterance within utterance, and at the same time also speech about speech, utterance about utterance" (Volóchinov, 2017, p. 249), that is: the alien discourse is not just a title, it is a constitutive statement full of meaning that alters the authorial discourse - it has theme, meaning and social evaluation.

Regarding the understanding of authorial discourse, in its context, the same author states: "it tends to the decomposition of the integrity and closure of alien discourse, to its dissolution and to the deletion of its boundaries [...]. It tends to erase the sharp, outward contours of alien word" (Volóchinov, 2017, p.258)

The authorial discourse and the alien discourse imbricate in language, even though they are diametrically different discourses. And these discourses are characterized by two types of discourses: the absolute, authoritarian discourse that does not undergo changes in its proposition and the relational or alternation discourse, a persuasive discourse based on listening in the face of the relations established from controversial statements in question.

We understand by absolute authoritarian discourse the discourse that recreates the truth or uses it for its interests, hiding concrete facts, scientific evidence such as in the constitution of the Bolsonarist discourse. We emphasize that the discursive positioning of denial is a non-authorial discourse that emanates from monological relations, due to the denial of dialogue or listening, a discourse that closes itself to the construction of its own consciousness in relation to the discourse of the other - the alien discourse.

\footnotetext{
${ }^{4}$ WhatsApp is a mobile application that enables conversations between people in real time, which can be private - conversation between two subjects - or in groups - when there are more than three participants -, when the construction of concrete statements takes place, through the exchange of texts, emoticons, videos, photos, and pictures that mark the discursive positioning of each subject regarding a particular thematic discourse.
} 
Relational or alternating discourse is the one that brings a relational proposition/theme, contestable or acceptable, based on events previously verified and cited in reliable sources, but whose proposition can be changed later, becoming another new position.

The relational discourse has the character of alternation that is established from the relations between people who are at the center of the thematic discussion, building their acts, positions constituted of points of view through their own and others' discourses, bringing propositions that can be refuted or accepted. In this case, there is no imposition of facts, there is an attempt to convince the other with evidence, but not to impose and eliminate the other as a result of having a contrary position, as foreseen by the absolute authoritarian discourse, the discourse of denial of events.

Thus, the members of the WhatsApp group "Academia Saudável” (AS group) (Healthy Academy), with their discursive positions, create tensions in favor or against the use of chloroquine and hydroxychloroquine in the treatment of the new coronavirus and denial of the pandemic. It is these discourses that constitute the materiality of our research for description and analysis in the following section.

\section{Description and Analysis of the Discourse Positions}

The conversation of the WhatsApp group "Academia Saudável" (AS group) (Healthy Academy) has 30 insertions, considering the alternations of discourses and some changes of subjects, typical of social networks. We made a cut in this materiality and used for the analysis 19 events grouped around the tensions on the use of medication for the treatment of Covid-19 and the denial about the pandemic, seeking to answer the question: how are the discursive positionings engendered in the controversy among these members regarding the use of chloroquine and hydroxychloroquine to combat Covid-19 constituted?

With the objective of better understanding the discursive positionings, constructed from the statements of the group members, we listed two key concepts that emerge from the selection and organization of the messages: "word and counterword of propagating treatment" and "word and counter-word of denial of reality".

These concepts constitute the two polemical discourses present in these conversations, which are: the absolute discourse - which does not enable dialogue by denying other voices - and the relational discourse, which recognizes the multiple voices and listens to voices outside the established dialogical relations. These relations are imbricated with the "here and now" of the events from 1 to 16 presented in the object of memory.

The materiality we are going to analyze begins when Marlena ${ }^{5}$ posts two alien messages, constituting Act 1:

\section{(Act 01) Marlena $\rightarrow$ Forwarded}

\section{Figure 1.}

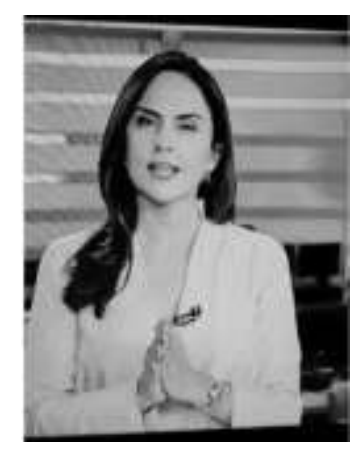

\footnotetext{
${ }^{5}$ All the names used here are fictitious, i.e. the real names have been substituted in order to ensure the anonymity of the participants.
} 
(TRANSCRIPTION OF THE REPORTER'S SPEECH): Talk about the best news: this one came from a pharmaceutical company in the U.S. state of California yesterday. They said they discovered a 100\% efficient antibody against the coronavirus. That's right: the company said that this antibody is able to provide protection to the organism and prevent contamination. Scientists examined millions of antibodies and identified those that bind to the Covid-19 protein and demonstrated 100\% effectiveness in blocking the entry of this virus nobody can stand anymore in human cells. Now the possible treatment needs to be approved by the agency that regulates health care in the United States... I spoke a little earlier here on Fala Brasil and if it happens the pharmaceutical company has already said that they are prepared and can already produce two hundred thousand doses per month. After the announcement of the discovery the pharmaceutical company's shares in the stock exchange went up more than $240 \%$.

$2: 24$

Marlena shares the video of the Rede Record news report, Fala Brasil (Act 01), in which the anchor of the network informs enthusiastically about a research of a pharmaceutical company, from the U.S. state of California, on an antibody with one hundred percent (100\%) efficiency against the new coronavirus. This report produces an effect in the population that there already exists a remedy to control the disease. We say this because of some indications: a) the speed with which the pharmaceutical company gave the news; b) the absence of the name of the company; c) the economic interest that made the company make money with the information. This first posted report, which is a word to spread the treatment, was the trigger for the other positionings of members with their counter-words that reflect the media discourse on the announcement of the discovery of antibodies to combat the coronavirus (see Event 14).

The discussion is about this post from Lidia, Tatiana and Eva's comments, in Acts 2 to 5:

(Act 02) Lidia

\section{Marlena}

- 11:16 vided

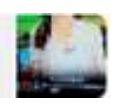

This news is just like the news about hydroxychloroquine, which was announced right at the beginning of the pandemic as a medicine that would cure people. Note: this information was announced by this same [TV channel] Record, deceiving people with false news. And a little more than two months later we are bitterly suffering the pain of the loss of loved ones. All of this is very sad!!

$1: 16$

(Act 03) Tatiane

Sorry but hydroxychloroquine is also saving a lot of people

$8: 43$

and I am seeing it in practice

$8: 43$

(Act 04) Lidia 
But not as it was announced. As a cure, otherwise we wouldn't have the number of deaths, I never ever said it didn't help, I just said it wasn't the cure they promised, I'm in two ICUs and I see that the use has to be done with caution, but unfortunately it was announced as "no more deaths from Covid-19, hydroxychloroquine has arrived".

$8: 46$

(Act 05) Eliana

Not a promise but an alternative for mild or moderate cases.

$8: 51$

Tatiane

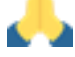

$8: 52$

Lidia (Act 02) responds to Marlena's speech, as a counter-word directed at the treatment propaganda, referring to the Rede Record video. She says that this report resembles a former one also about hydroxychloroquine, from the same broadcaster, which spread the cure for Covid-19, deceiving the viewers. We notice here that Lidia not only resumes Marlena's initial conversation, but brings a blunt positioning regarding the veracity of the reports of this broadcaster (Record).

Tatiane (Act 03) introduces the first discursive tension - the use of chloroquine and hydroxychloroquine drugs as a valid treatment for Covid-19 - and incisively states that hydroxychloroquine is saving many lives.

Lidia, in a responsive tone (Act 04), brings a counterword of propagating the treatment by hydroxychloroquine brought by Tatiane. Eliana responds firmly (Act 05) to Lidia with the word "alternative" - consequently, a hope in this treatment of the new coronavirus that has become a pandemic chaos, introducing her speech that the use of hydroxychloroquine is an option that cannot be ignored. We highlight that this discussion is a refraction of President Jair Bolsonaro's institutional position of extending the protocol for the use of medications (see Event 15).

Next, Eliana posts an amen emoji, agreeing with Tatiane's discourse, reaffirming her position regarding the use of hydroxychloroquine with a discursive tone favoring the word "alternative" as a treatment to Covid-19.

The discussion continues around the first tension in Acts 06 to 08:

(Act 06) Tatiana

Eliana

I never understood hydroxychloroquine as a cure, but rather as an alternative

9:03 


\author{
(Act 07) Lidia \\ But unfortunately this is not how it was presented by Record \\ 9:07
}

(Act 08) Nara

Eliana

Exactly, and thus avoiding reaching death. An alternative is better than nothing.

$9: 11$

Tatiane discusses (Act 06) the use of hydroxychloroquine, agreeing with Eliana who also understands that this medication is not a cure, but an alternative, something like a palliative treatment for the disease.

Lidia clarifies (Act 07) that the content of her discursive positioning is in opposition to the discourse of the Rede Record broadcaster, because it does not place it as a treatment or alternative, but as the end of the pandemic.

Nara emphasizes the discussion about the use of chloroquine (Act 08) bringing her speech closer to Eliana and Tatiane's position that this medication is to be considered an alternative until the official release of a response from the scientific community. This member asserts a convincing position of using chloroquine as an alternative, or palliative in our interpretation, to avoid the death of people in this pandemic. The controversy of the use of medications comes from the presidential speech when authorizing large-scale production, refracting in the speech of some who see chloroquine as the solution, the cure for the Covid-19 problem.

This first tension is further extended in Acts 09 and 10:

(Act 09) Amanda

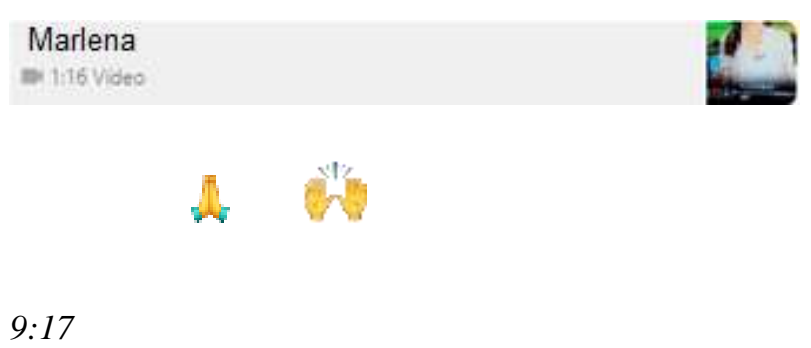

(Act 10) Lidia

Communication is really a sad story, note that I referred only to the Record news report, which in today's post says the North American company has 100\% of the discovery of the antibody that fights the virus. And there, I only compared it with the news of the same Record that said that the use of hydroxychloroquine was a $100 \%$ cure, I was only referring to the position of the specific Record report, and not to other reports and experts who say its use is an alternative

$9: 18$ 
Amanda (Act 09) responds to Marlena with emojis of amen and gratitude regarding the dissemination of the story of Record Broadcaster, which deals with the discovery of an antibody with one hundred percent (100\%) efficiency against coronavirus. The member demarcates her discourse of propagating the treatment, believing in the broadcast as a solution to the pandemic, thanking the other member for the information.

Lidia (Act 10) states that her contestation is about the reports broadcasted by the Record TV station. She makes the comparison between the video post, which deals with the discovery of the antibody, and the report "Medicine for malaria can have good results against coronavirus", in the interview that took place on March 19, 2020 (see Event 02).

She states that her initial discursive positioning was to warn about the discourses of the Record Broadcaster that influences greatly the discourses of the subjects that are on a daily basis in various WhatsApp conversations, building their own authorial discourses about the surrounding pandemic.

Pablo starts the second discursive tension with a negationist position about the pandemic, an absolute and authoritarian discourse, since some members take part and withdraw from the discussion. This occurs between Acts 11 to 14 :

\section{(Act 11) Pablo \\ Good morning.}

Guys we are going through a very serious situation, where people are losing their livelihoods. Others are becoming desperate, however this group was focused on gym issues, but I can see that it turned out to be of doctors expert in Covid-19, because the only things that are posted are news about these pandemic that ravages the planet.

This is a subject that does not help me at all, and I am fed up with this subject [...]. I am leaving the group because this subject does not interest me. When the academy issue comes back, add me to the group again. 9:40

\section{Pablo left}

(Act 12) Nara

\section{Pablo}

\section{Good morning.}

I share the same opinion. Teachers Fred or Valdo or Vilma, please include me again, as soon as we can return to gym classes. Thank you and a kiss in your heart.

$9: 44$

Nara left

(Act 13) Iris

I agree !... teachers I'll be waiting for the academy to open, which I hope will be soon.

I look forward to hearing from you in my PM. Thanks

$9: 48$

Iris left 


\section{(Act 14)}

\section{Sidney left}

In this second tension (Act 11), Pablo introduces a word of denial of reality: he positions himself contrary to the discussion of other topics that are not related to gym issues, refusing to discuss pandemic-related matters, because he claims to be at the limit with this conversation. Without enabling any dialogue, he leaves the group immediately.

In this tension from Pablo's speech, Nara (Act 12) shows a similar positioning and decides to leave the group, asking the teachers to be included again when classes return and ends her speech, thanking and saying goodbye with an affectionate tone represented by emoticons.

In this same position, Iris (Act 13) and Sidney (Act 14) left, opposing the discussion about the new coronavirus within the group, marking their positions of denial of dialogue on this subject.

These speeches are strongly marked by positions of denial advocated by the Bolsonarist group that are assumed by some members who refuse to dialogue, refusing to discuss an ecological-health crisis with a global dimension, which has changed the social, economic, and political life of society as a whole (see Event 04).

The second tension is further intensified in acts 15 to 17:

\section{(Act 15) Karla}

\section{Good morning}

I find it difficult not to talk about this subject because we are living something new, full of mysteries and a lot of pain, of losing those we love and know.

But I like to read something about the subject because information is everything, we just have to filter it, and I respect everyone's opinion.

\section{I believe we will SING THE HYMN OF VICTORY}

$9: 54$

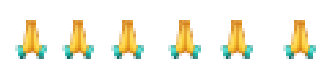

(Act 16) Maria

Karla

It's true.karla.. $\$$. Losses, many afflictions, and when I do not bury myself I sleep. The human being, right Katia, each with his or her own thoughts.

Let's pray

$9: 59$

(Act 17) Fred

Guys, I understand everyone's position, feel free to make the decision that suits you best.

To those who are leaving, when the activities return to normal, we will add everyone again.

10:04 
Some members position themselves in defense of the concrete need to maintain the dialogue. Therefore, Karla (Act 15) enters the conversation with a responsive and dialogical tone, with a counterword contrary to the denial of reality, that is, valuing the listening of all positions. She also makes a comment on the attitudes of the group's colleagues towards the pandemic, highlighting the recognition and respect towards the other's position.

Maria (Act 16) also enters this dialog and expresses agreement with Karla's message, emphasizing that when the subject is not of her interest, she deletes the message, but does not leave the group or cancel the other because each human being has a different thought. Karla and Maria in a dialogical perspective in the light of the fundamentals of love and respect for the other, highlight the need to listen to the alien discourses in order to build their own speeches.

Fred (Act 17), who is one of the teachers and responsible for the AS group, enters this conversation and says he understands, assuming a friendly position. It is essential that he not be the pivot of any dropout from the academy. Therefore he cannot take a position in favor of any group of students.

This member seeks to ensure the academy's goal, which is a healthy body and a friendly atmosphere for everyone. He does not silence any of the members and leaves them at ease, assigning responsibility to each one, i.e., each one is responsible for his/her actions.

The response marked in this tension blatantly presents the defense of dialogue in counterpoint to the Bolsinarian discourse and acts of denial of dialogue that is related to the non-acceptance of different positions, such as was seen in the dismissal of Luiz Henrique Mandetta's, former Minister, and the request for Nelson Teich's resignation. (See Events 11 and 13).

Resuming the tension of the use of Chloroquine, Gael (Act 18) announces

$$
\text { (Act 18) Gael } \rightarrow \text { Forwarded }
$$

Figure 2.

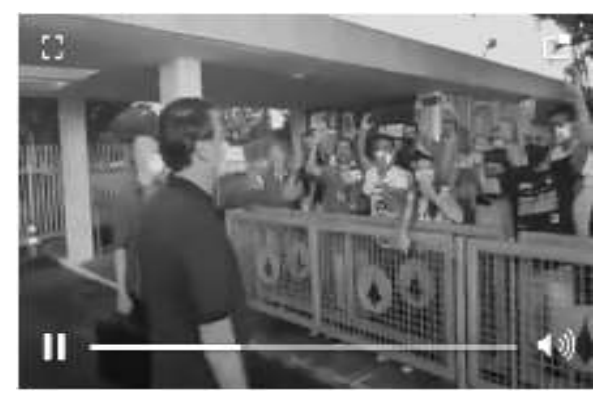

(Transcription of the video with an audience in front of the Esplanada Presidential Residence singing):

"Chloroquine, chloroquine is from SUS/ I know you can cure me/ In the name of Jesus". $10: 40$

Gael enters the dialogue (Act 18) restarting the discussion on "treatment" through word "cure" by sharing the video with a parody. This positioning shows the refraction of the discourse that praises homeland and religiosity, strong brands such as "SUS" and "Jesus" portrayed in the parody in defense of the medication for the "cure" of Covid-19 in a "miraculous" way. This approximates and reinforces the ideological discourse of the current government that is founded on the triangulation godnation-family. 
Concluding the group conversation around the pandemic, Rosa (Act 19) forwards a "Good morning!" post, which introduces an alien discourse with the theme of social isolation represented in this genre by image and words imbricated. She uses a tone of awareness, without losing tenderness and respect, through the post on social isolation. She also emphasizes the groups considered most vulnerable: those who experience greater risk factors and the most contagious ones, the elderly and children, respectively.

\section{(Act 19) Rosa}

Figure 03

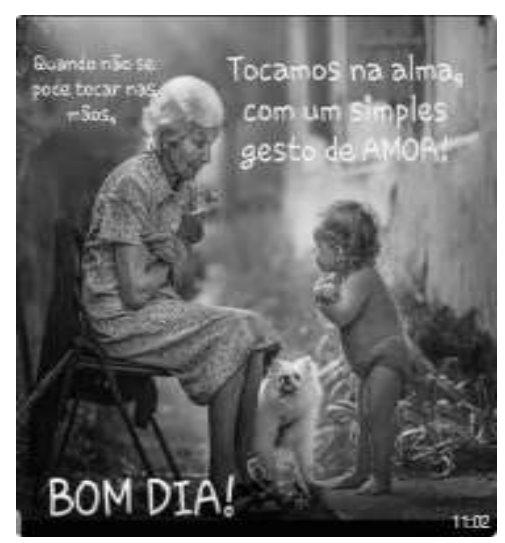

11:02

Thus, with the analysis, we understand that the marks of the refraction of the Bolsonarist discourse become evident in the statements constituted in the conversations of the AS group, considering that the discursive positionings most present in the face of the tensions established are the word "alternative", which we interpret as palliative, with medications that do not present scientific evidence regarding the benefits in the treatment of Covid-19, and the word of denial, focusing on the counter dialogue due to the economic consequences provided by the pandemic. Besides, there is the non-recognition of the ecologicalhealth crisis caused by a problem with global proportions.

The texts presented in the memory of the object mostly reveal institutional and authoritarian discourses, which do not consider scientific research, refracting other positions that propagate the Bolsonarist discourse on the polemical use of drugs. Note that such discourses are part of the tensions in the conversations, in a tone that some members who defend the use of these medications assume a discursive positioning of total defense and others oppose it.

\section{Concluding Remarks}

When someone gets sick, the desire for a medicine with successful recovery is almost immediate. This desire is strong especially in a society that expects a cure for any and all diseases, perhaps this is why the debate on social networks about drugs that can treat Covid-19 is so full of tensions. Therefore in this article we discuss the established discursive positionings that provided tensions about the treatment of Covid-19 among the members in the AS group.

The conversations in this group engender two discursive positionings about the pandemic. The first one discusses the use of chloroquine and hydroxychloroquine as treatment for Covid-19 in a tense and responsive way; the second one already denies this discussion about the pandemic with a position of antidialogue when they withdraw from the group. 
In this sense, from the dialogical analysis of the statements - authorial and alien - which are refracted from other discourses, we ponder that each positioning is related to other one, as in a chain of meaning. In the context of this conversation of the gym members, the marks of the refraction of the alien discourse from discursive tensions become evident.

These tensions are constituted from the multiple concrete statements that were constructed during the conversation in the AS group. We can consider that the members express their ideologies, beliefs and values through videos, images, texts, emoticons and even by leaving the group.

Thus, from our materiality, it is coherent to state that, during the conversation, some members enter into discursive tensions seeking to demarcate their positions, through silence or refusal to participate in the discussion - or even leaving the group -, while others put themselves in a position of dialogic listening when facing controversial discussions, such as about the coronavirus pandemic.

We emphasize that the discursive positions established in the social relations of the WhatsApp group are reflections of the discourses of others, which circulate in the mediatic, political and scientific fields. These discourses permeate the authorial discourses and, in such a context - full of insecurity, fear and anguish - generate controversies in the conversations.

We also notice that all these fields are not neutral. They produce and propagate authorial and alien discourses for the subjects of various social network groups. And they appropriate them to organize their own discourses with filters of consciousness. It is in this formulation in tension that an appreciation, a caution, a choice is necessary for these subjects to guarantee their dialogic character, constitutive of their discursive positions.

Thus, in this discussion, two discourses emerge: the absolute discourse, which does not allow other voices, denying dialogue and, thus, is characterized as an authoritarian discourse, and the relational discourse, that of alternation, which admits multiple voices, that is, the discourse that considers listening to other speeches, based on the established relations and the topic discussed.

\section{References}

Baker, P., Rogers, K., Enrich, D., Haberman, M. (2020). Trump's Aggressive Advocacy of Malaria Drug for Treating Coronavirus Divides Medical Community. The New York Times. https://www.nytimes.com/2020/04/06/us/politics/coronavirus-trump-malaria-drug.html.

Bakhtin, M. M. (1993). Toward a philosophy of the act. Austin: University of Texas Press. Translation and notes by Vadim Liapunov and Michael Holquist.

Bakhtin, M. M. (1986). Speech genres and other late essays. Austin: University of Texas Press. Translated by Vern W. McGee.

Bakhtin, M. (2010). The Discourse on Dostoevsky. In: Problems of Dostoevsky's Poetics. Translation direct from Russian, notes and preface by Paulo Bezerra. Rio de Janeiro: Forensic University, 2010, p. 207-310.

Bakhtin, M. M. (2016). Os gêneros do discurso. Editora 34.

Bakhtin, M. M. (2017). Por uma metodologia das ciências humanas. In BAKHTIN, M. M. Notas sobre literatura, cultura e ciências humanas (pp. 57-79). Editora 34.

Batista, E. L. (2020). Empresa diz ter encontrado anticorpo que cura coronavírus, mas não tem comprovação. Folha S.Paulo. https://www1.folha.uol.com.br/equilibrioesaude/2020/05/empresa-diz-ter-encontrado-anticorpo-que-cura-coronavirus-mas-nao-tem-comprovacao.shtml.

BBC News. (2020). Em rede nacional, Bolsonaro critica fechamento de escolas e comércio e compara coronavírus a 'resfriadinho'. BBC News. https://www.bbc.com/portuguese/brasil-52028945.

Brasil247. (2020). Bolsonaro diz que não há estudos comprovados sobre cloroquina, mas mandou produzir mais. BRASIL247. https://www.brasil247.com/poder/bolsonaro-diz-que-nao-ha-estudos-comprovados-sobre-cloroquina-mas-mandou-produzir-mais.

Cancian, N., Fernandes, T., Chaib, J., \& Coletta, R. D. (2020). Após ultimato sobre cloroquina, Teich pede demissão do Ministério da Saúde. Folha de S.Paulo. https://www1.folha.uol.com.br/equilibrioesaude/ 2020/05/apos-ultimato-sobre-cloroquina-teich-pede-demissao-do-ministerio-da-saude.shtml.

Cancian, N., \& Saldaña, P. (2020). Governo cria protocolo para dar cloroquina a pacientes graves com Covid-19. Folha de S.Paulo. https://www1.folha.uol.com.br/equilibrioesaude/2020/03/governo-cria-protoloco-para-dar-cloroquina-a-pacientes-graves-com-covid-19.shtml.

Cassio, J. (2020). Mandetta humilha Bolsonaro, diz que vai manter isolamento e que cloroquina só por cima da ciência. DCM. https://www.diariodocentrodomundo.com.br/mandetta-humilha-bolsonaro-diz-que-vai-manter-isolamento-e-que-cloroquina-so-por-cima-da-ciencia/. 
Cidadeverde.COM. (2020). Governo do Piauí autoriza compra de cloroquina para tratamento da Covid-19. Cidade Verde.com. https://cidadeverde.com/coronavirus/105619/governo-do-piaui-autoriza-compra-de-cloroquina-para-tratamento-da-covid-19.

FGV. (2020). Novo coronavírus (Covid-19): informação e orientação protejam-se. FGV.

G1. Globo. (2020). Ministério divulga protocolo que libera no SUS uso de cloroquina até em casos leves de Covid-19. G1.globohttp://bibliotecadigital.fgv.br/dspace/bitstream/handle/10438/28951/informativo_coronavirus_estudo_completo_03_1_1.pdf?sequence=1\&isAllowed =y.. $\quad$ https://g1.globo.com/bemestar/coronavirus/noticia/2020/05/20/ministerio-da-saude-divulga-protocolo-que-libera-uso-de-remedio-para-malaria-paracovid-19.ghtml.

G1. Globo. (2020). Autores pedem 'retratação' de estudo sobre cloroquina publicado na 'The Lancet' e pesquisa é 'despublicada'. G1 Globo.com. https://g1.globo.com/bemestar/coronavirus/noticia/2020/06/04/the-lancet-publica-nota-de-retratacao-sobre-estudo-com-cloroquina-e-hidroxicloroquina-paracovid-19.ghtml.

Hime, F. \& Costa, G. B. (2020). 50 tons de nada a ver: os estudos usados para vender a cloroquina. Revista Questão de Ciência. https://www.revistaquestaodeciencia.com.br/questao-de-fato/2020/05/22/50-tons-de-nada-ver-os-estudos-usados-para-vender-cloroquina.

Leão, A. L. (2020). País 'não sabe se escuta o ministro ou o presidente', diz Mandetta. G1 Globo.com. https://oglobo.globo.com/brasil/pais-nao-sabe-seescuta-ministro-ou-presidente-diz-mandetta-24367167+\&cd=1\&hl=pt- R\&ct=clnk\&gl=br.

Ludke, M., \& André, M. (1986). Educational research: Qualitative approaches. Sao Paulo: EPU

Maisonnave, F. (2020). Autores de pesquisa sobre cloroquina no Amazonas recebem ameaças. UOL Folha de S. Paulo. https://www1.folha.uol.com.br/equilibrioesaude/2020/04/autores-de-pesquisa-sobre-cloroquina-no-amazonas-recebem-ameacas.shtml.

Oliveira, P. I. (2020). Organização Mundial da Saúde declara pandemia de coronavírus. OMS-BRASIL. https://agenciabrasil.ebc.com.br/geral/ noticia/202003/organizacao-mundial-da-saude-declara-pandemia-de-coronavirus.

OMS. (2020). Preguntas frecuentes: qué es um coronavírus? Organización Mundial de la Salud. https://www.who.int/es/emergencies/diseases/novelcoronavirus-2019/coronavirus-disease-answers?query=conceito+novo+coronavirus.

Pinheiro, C. (2020). Covid-19 é doença sistêmica: conheça estragos e sintomas fora dos pulmões. Veja Saúde. https://saude.abril.com.br/medicina/ covid-19-edoenca-sistemica-conheca-estragos-e-sintomas-fora-dos-pulmoes/.

Reis, F. (2020). RDC 351/2020 Anvisa: inclusão da Cloroquina e Hidroxicloroquina na portaria 344/98. Notícias Pfarma.com.br. https://pfarma.com.br/noticia-setor-farmaceutico/legislacao-farmaceutica/5329-rdc-351-2020-anvisa.html.

RFI. (2020). Según The Lancet cloroquina e hidroxicloroquina no son eficaces contra la Covid-19. RFI. http://www.rfi.fr/es/salud/20200523-the-lancet-lacloroquina-no-es-eficaz-contra-el-coronavirus-covid-19.

Rowland, C. (2020). Agência de saúde dos EUA autoriza o uso de hidroxicloroquina e cloroquina contra o coronavírus. Estadão Saúde. https://saude.estadao.com.br/noticias/geral,agencia-de-saude-dos-eua-autoriza-o-uso-de-hidroxicloroquina-e-cloroquina-contra-o-coronavirus, 70003254115.

Sputniknews Brasil. (2020). Bolsonaro diz que novo protocolo sobre uso da cloroquina será editado hoje. Sputniknews Brasil. https://br.sputniknews.com/brasil/2020052015600331-bolsonaro-diz-que-novo-protocolo-sobre-uso-da-cloroquina-sera-editado-hoje/.

Veleda, R., \& Waltenberg, G. (2020). Empresário que produz a cloroquina é militante bolsonarista. Metrópole. https://www.metropoles.com/brasil/politicabrasil/empresario-que-produz-a-cloroquina-e-militante-bolsonarista.

Volóchinov, V. (2017). Marxismo e Filosofia da Linguagem: problemas fundamentais do método sociológico na ciência da linguagem (pp. 249-262). Editora 34. 